\title{
Climate change impacts on spatial distribution, tree-ring growth, and water use of stone pine (Pinus pinea L.) forests in the Mediterranean region and silvicultural practices to limit those impacts
}

\author{
Kaouther Mechergui ${ }^{(1-2)}$, \\ Amal Saleh Altamimi ${ }^{(3)}$, \\ Wahbi Jaouadi ${ }^{(1-2)}$, \\ Souheila Naghmouchi ${ }^{(2)}$
}

\begin{abstract}
Stone pine (Pinus pinea L.) has been cultivated since centuries in Mediterranean areas for its products and economic benefits, including edible pine nuts, timber, mushrooms, firewood, and grazing. However, current management objectives of stone pine stands also include recreational use, biodiversity conservation, protection from soil erosion, and $\mathrm{CO}_{2}$ fixation. Stone pine stands are considered to be among the ecosystems most vulnerable to climate change, and the current increase in drought frequency in the Mediterranean Basin has been shown to negatively impact their long-term establishment. Understanding the effects of climate change on the distribution, tree-ring growth and water use of stone pine forests can help assessing the adaptive capacity of the species, and developing management programs aimed at its conservation. This paper reviews the impacts of climate change on stone pine in the Mediterranean region. The high sensitivity of stone pine to climate change has been widely demonstrated in that: (i) climatic models predict the loss of suitable habitats and the shift of its geographical distribution in the next future; (ii) tree-ring analysis showed that winter and spring rainfalls have positive effects on growth, whereas high spring temperature has a negative effect; (iii) the strategy of stone pine to cope with water deficit affects the processes regulating its growth, including wood formation, leading to peculiar tree-ring anatomical features such as intra-annual density fluctuations. The silvicultural interventions and the most effective management strategies for stone pine forests are reviewed and discussed in the context of current climate change in the Mediterranean Basin.
\end{abstract}

Keywords: Stone Pine, Climate Change, Spatial Distribution, Tree-ring, Silvicultural Practices, Mediterranean Area

\section{Introduction}

Climatic models predict an increase in aridity in many parts of the world during the twenty-first century, which is likely to be more intense in the Mediterranean Basin than in other regions (Lopez-Tirado \& Hidalgo 2016). Climate forecasts for the Mediterranean region anticipate increasing temperatures, decreasing rainfall, longer dry spells, more frequent heat waves, and heavier precipitation events, all of which will exacerbate the existing problems of soil loss and desertification (Kovats et al. 2014). The strong irregularity of rainfall in the Mediterranean area, which can trigger severe/extreme droughts and floods, results in a high plant vulnerability to interannual rainfall variability and extreme event occurrence (Freire et al. 2019). Mediterranean forests provide a variety of goods (timber, firewood, and mainly non-wood forest products such as pine nuts, cork, aromatic plants, game, and mushrooms) and high-value services (recreation, protection from erosion, livestock grazing, biodiversity conservation, $\mathrm{CO}_{2}$ sequestration, and water balance regulation), which are important for ensuring the maintenance of human society. Multifunctionality is there- fore an important characteristic of Mediterranean forest management (Pardos et al. 2015).

Sensitivity to climate change and anthropogenic disturbances are common features of Mediterranean forests, which grow under dynamic and manipulated environmental conditions (Cutini et al. 2014) Many of the projected changes in climate, as well as the indirect effects of these changes, are likely to have a negative impact on forest systems (Keenan et al. 2015). The current increase in drought frequency has been shown to detrimentally affect the long-term establishment of Mediterranean forests. Among other effects, an increase in drought events might have an adverse impact on plant regeneration (Doblas-Miranda et al. 2016). Freire et al. (2019) attest that the ongoing climate change is causing a decrease in rainfall over all seasons, and especially in the spring during cone growth, and it is more severe in the most critical regions for stone pine. Correspondingly, the increase in temperature, mainly in summer, leads to the death of cones with one or two years of maturation. Dendroecological studies in the Mediterranean basin have demonstrated that tree-ring 


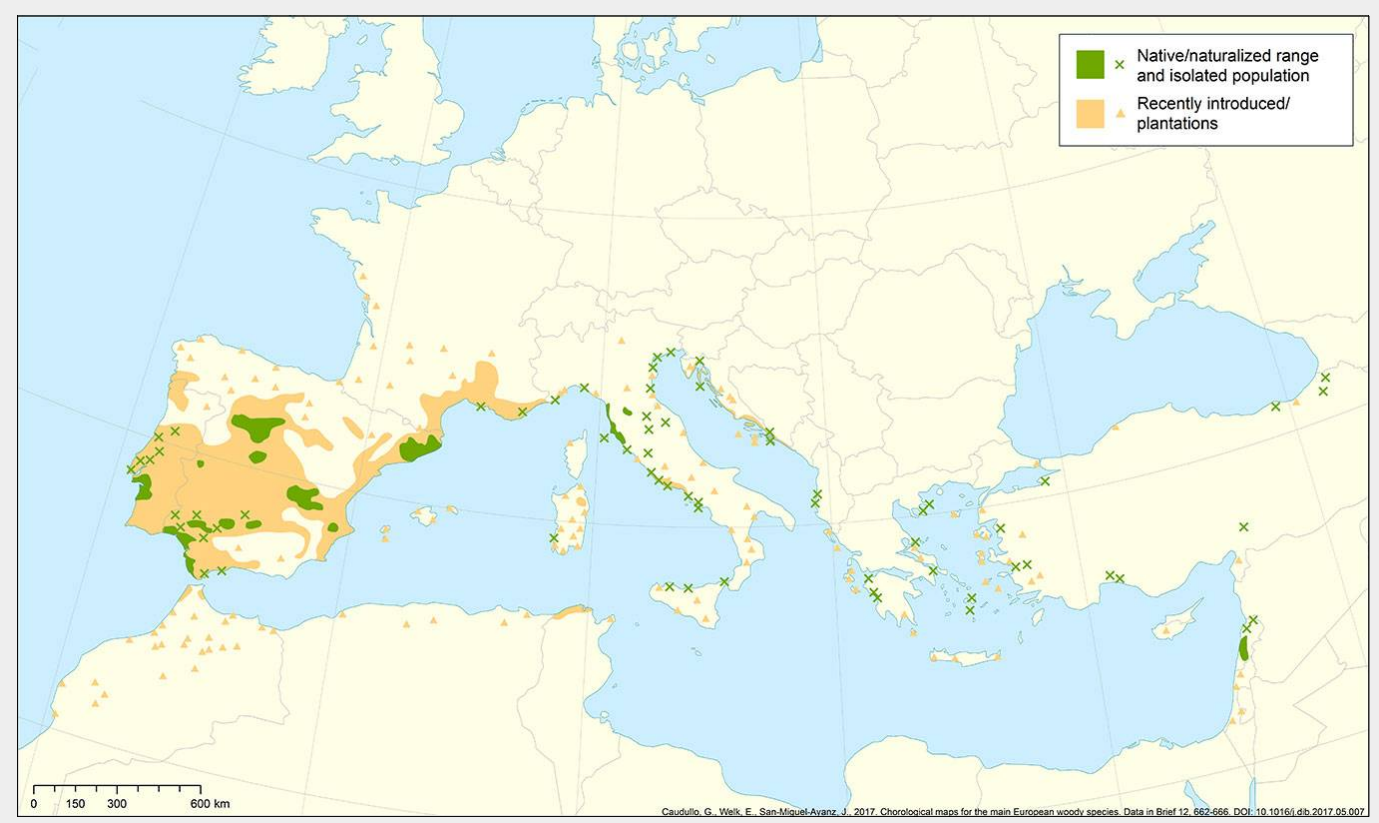

Fig. 1 - Main distribution of Mediterranean stone pine forests (Caudullo et al. 2017).

data can be used as climate proxies in this region (Gea-Izquierdo et al. 2011, Vieira et al. 2015). Tree-ring widths usually show variation over the life of a tree; therefore, such age/size trends need to be estimated and removed from time series in order to detect the evidence of climatically-driven tree growth. Regarding the interdependence of increasing temperatures and decreasing water availability, Sánchez-Salguero et al. (2015) showed that growth is more sensitive to drought than to temperature in several Mediterranean species, which is in accordance with the findings by Calama et al. (2019). Understanding the effects of climate change on the ecology of Pinus pinea forests can help to assess the adaptive capacity of the species, and develop management programs aimed to ensure the conservation of its populations (Natalini et al. 2016).

The study of current and future potential distribution of suitable habitats for stone pine under climate change is critical (Akyol \& Orucu 2019). It is well known that climate plays a determining role in the large-scale distribution of species (Guisan \& Thuiller 2005). Species distribution models (SDMs) are used to determine the ecological niche of species, and estimate their potential distribution ranges in terms of regional ecology and biogeography (Franklin 2013). Projections of future climate conditions in the Mediterranean Basin predict substantial changes, such as increased average temperature, reduced precipitation, and alterations in annual patterns (Zank et al. 2014).

In this context, it is important to understand the impact of these changes on the distribution of stone pine in the Mediterranean forests by spatial modeling, as well as growth responses to changes in precipitation and temperature through tree-ring analyses, and the strategies of the species to cope with water deficit, in order to introduce silvicultural practices to limit these impacts. The objective is to use the available results of research to provide guidance for the management of stone pine stands established in the Mediterranean region in the context of ongoing climate changes.

\section{Importance of stone pine stands in Mediterranean forests}

This review focuses on an emblematic Mediterranean species, stone or umbrella pine (Pinus pinea L.), a native/naturalized species to Southern Europe (Quézel \& Médail 2003) spread from the Portuguese Atlantic coast to the shores of the Black Sea and the slopes of Mount Lebanon (Fig. 1), from sea level to $1000 \mathrm{~m}$, and occasionally up to $1600 \mathrm{~m}$ a.s.l. (Quézel \& Médail 2003). Stone pine is widely present in coastal habitats, where it has extensive ecological, landscape, recreation, and soil conservation uses. According to Mutke et al. (2012), stone pine forests are estimated to cover 0.7 million ha across the Mediterranean region (Fig. 2). The most important distribution areas are in Spain (470,000 ha), Portugal ( $80,000 \mathrm{ha})$, Turkey (50,000 ha), and Italy (40,000 ha). More than half of this area is the result of protective afforestation (Martinez et al. 2004).

Stone pine plantation dates back to the Roman period, and it was traditionally cultivated for timber and pine nuts. However, its recreational and landscape value has increased in recent decades (Mazza et al. 2011), and is currently used for the consolidation of sand dunes and protect soil from erosion (Cutini et al. 2014). Indeed, its multi-layered root system allows mature trees to extract water at different depths and from various sources (Cutini et al. 2013). Along the Italian coastline, Pinus pinea forests have an important environmental and historical value; the species has been systematically planted here since ancient times, mostly for cone and wood pro- duction, as well as for coastline protection (Arduini \& Ercoli 2012).

Pinus pinea forests are usually managed as multifunctional forests that provide timber, biomass, non-wood forest products (such as pine nuts and truffles - Bravo et al. 2011), soil protection, sand dune stabilization, biodiversity refuge, space for public and recreational activities, and carbon sequestration (Martinez et al. 2004). Yet, the most profitable activity for forest owners is cone production, more than timber and other products (Ovando et al. 2010). Given the high nutritional value and the unique flavor of stone pine nuts, their demand is globally increasing, with the consequent increase in market price (Fady et al. 2004). According to Loewe \& Delard (2019), the prices of Pinus pinea edible nuts has increased from $€ 25 \mathrm{~kg}^{-1}$ in 2010 to $€ 45 \mathrm{~kg}^{-1}$ in 2013. Stone pine kernel production in Italy ranges between 40 and $120 \mathrm{~kg} \mathrm{ha}^{-1}$, which is equivalent to 10 to $30 \mathrm{~kg}$ of pine nuts ha(Mutke et al. 2007). Moreover, Ovando et al. (2010) showed that stone pine afforestation offers positive net benefits to landowners, taking into account carbon prices of up to $45 \in \mathrm{tC}^{-1}\left(12.3 \in \mathrm{tCO}_{2}^{-1}\right)$. Furthermore, stone pine has proven to be a suitable species in combined agroforestry systems for both nuts and timber production, intercropped with agricultural crops, and animal grazing (Loewe \& Delard 2019). Those authors found that the annual income derived from crops and animals is relevant for the household economy, especially during the first years.

Recently, Calama et al. (2020) reported a generalized decline in the kernel-per-cone yield in Pinus pinea forests located in different Spanish regions, revealing reductions of up to $50 \%$ in the final kernel-per-cone yield in the most drought affected regions. Such reduction over different years and provenances with contrasting climates suggests the implication of a biotic factor that 
can be aggravated in extreme drought years. Further, Natalini et al. (2016) suggested that the Pinus pinea species has a plastic response to warmer and drier climates that can vary among populations, and some measure of such variability should be considered in long-term forecasts of vegetation dynamics.

\section{Spatial modelling of stone pine distribution under climate change}

Akyol \& Orucu (2019) found that the most important bioclimatic variables affecting the potential distribution of $P$. pinea are the minimum temperature of the coldest month (Bio6), annual precipitation (Bio12), and precipitation of the wettest quarter (Bio16); whereas, Serra Varela (2018) found that annual mean temperature (Bio1), temperature seasonality (Bio4), precipitation seasonality (Bio15), precipitation of the warmest quarter (Bio 18), and precipitation of the coldest quarter (Bio 19) are the main drivers of stone pine distribution. Simulation models under two different future climate change scenarios predicted that $P$. Pinea will lose suitable habitats and will shift toward northern and higher elevation sites. For example, Akyol \& Orucu (2019) showed that $P$. pinea in Turkey will shift its geographical distribution in the future and experience losses of habitat, particularly in the western and southern parts of Turkey. According to Akyol \& Orucu (2019), the potential distribution of $P$. pinea in the years 2050 and 2070 will decrease under the representative concentration pathway (RCP) 4.5 and RCP 8.5 scenarios. Pecchi et al. (2020) reported that by 2050 under RCP 4.5 scenario, the spatial distribution of suitable habitats for stone pine pure stands will significantly decrease in Italy compared to other hardwood species.

Freire et al. (2019) reported that the impacts of medium-term climate change on Mediterranean forests are the displacement and migration of species from south to north, and from inland to the coast (García-Güemes \& Calama 2015). According to Lopez-Tirado \& Hidalgo (2016), stone pine could expand its potential area in southern Spain by approximately $17 \%$. Overall, stone pine would be the most suitable pine species in the western and northeastern zones of the study area. Similar results were obtained by Bede-Fazekas et al. (2014), who stated that most of the distribution of stone pine in Spain will remain viable by the middle twenty-first century.

Calama et al. (2011) analyzed the spatial and temporal patterns of variability in cone production in stone pine forests located in the Spanish Northern Plateau. Those authors found that the annual production of stone pine cones at the tree level showed a skewed and zero-inflated distribution, together with a large interannual variability, with a regional average ranging from 0.2 to $6.3 \mathrm{~kg}$ tree $^{-1}$. This variation was largely synchronized among the trees and stands throughout the study area, confirming the

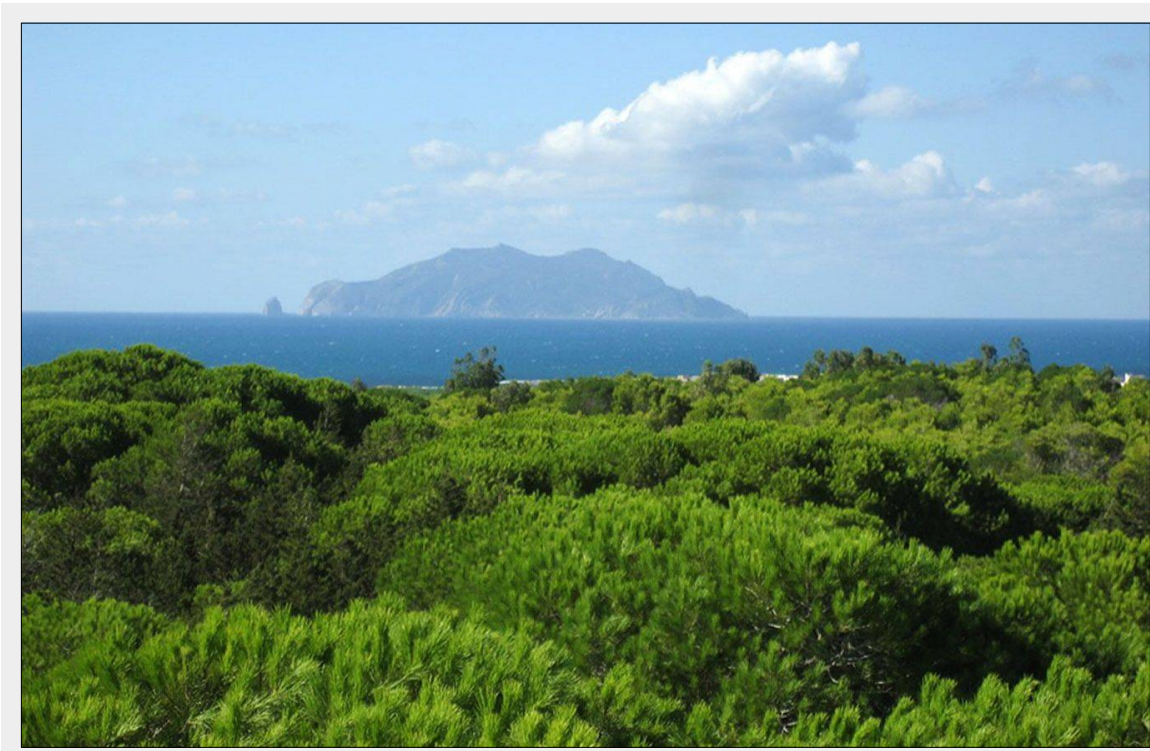

Fig. 2 - Stone pine forest in Cap Bon (Tunisia).

masting habit of the species. Apparently, climatic factors are the main determinants of the masting behavior, explaining about $60 \%-80 \%$ of the temporal variation in cone production at the regional scale over a series of 13 years, correctly discriminating between good and bad crop years.

\section{Temperature and precipitation effects on tree-ring growth}

In a study on the variation of stone pine productivity in relation to climate in Spain, Natalini et al. (2013) found that winter and spring rainfall has a positive effect on growth, whereas high spring temperature negatively affects stone pine growth. These authors found that growing performances are positively correlated with the Palmer Drought Severity Index (PDSI) and annual rainfall, and negatively correlated with the maximum average annual temperature, which agrees with the findings of Loewe et al. (2017) for height growth in Chile.

\section{Precipitation effects}

Dendroclimatological analyses indicate that the positive moisture balance in the spring is the main factor favoring the radial growth of Pinus spp. in the Mediterranean regions (Piraino et al. 2013). Winter precipitation is largely responsible for growth rates of stone pine (Thuiller et al. 2003a, $2003 \mathrm{~b}$ ), and the high sensitivity of growth to precipitation has been confirmed by Raventos et al. (2001). Loewe et al. (2016) identified climatic variables (e.g., annual water deficit) that significantly influence seed number per cone in stone pine, and also the biometeorological variables that account for the physiophenological phases involved in this trait determination. Akkemik (2000) found that precipitation in the current year has a significantly positive influence on the tree-ring growth, and observed a significant positive relationship between tree-ring width and monthly precipitation. Cherubini (1993) concluded that precipitation plays the most important role in tree-ring growth in Pinus pinea L. Calama et al. (2019) detected a positive relationship between rainfall and growth, extending back to the precipitation of previous autumn and winter seasons. Similar findings have been reported in previous studies on dendroecological growth-climate relationships for the species (Mazza et al. 2014, Natalini et al. 2015, 2016, Jaouadi et al. 2018). Total rainfall occurring during the period from October of the previous year to September of the current growth year as well as mean temperature in May and June, are the main climatic factors driving secondary growth in Pinus pinea (Calama et al. 2019). Novak et al. (2011) reported that dry conditions during January to May and high temperatures during late winter and spring were the main climatic factors promoting missing rings in Pinus pinea. This has suggested that the observed increase in missing rings could be related to stress conditions caused by reduced precipitation (De Luis et al. 2009). El-Khorchani et al. (2007) also noted the impact of hydric balance on diameter growth, and water stress can be intensified in sandy soils, where water availability decreases drastically in dry years (Thabeet et al. 2007). Accordingly, Mazza \& Manetti (2013) reported that low precipitation is the main factor causing a decrease in radial growth, an effect that lasts over long periods. Mazza et al. (2014) showed a clear grouping of $P$. pinea tree ring growth related to regional variation in climatic features, which likely reflects the existence of different responses strongly dependent on geographical variability in rainfall inputs during the periods that most influence tree ring formation. The decrease in winter-early spring rainfall appeared to be the principal climate-driven growth pattern distinguishing the chronologies. 


\section{Temperature effects}

The most important environmental variable affecting survival and distribution of Pinus pinea in the Mediterranean is the average temperature of the coldest month (Thuiller et al. 2003a, 2003b). Loewe et al. (2016) showed that temperature has the highest impact on stone pine growth; in particular, vertical growth was more than twice in sites with low annual average temperature and high winter thermal oscillations. Tree ring development in P. pinea is negatively influenced by drought in the late spring and summer (from March to September) and enhanced by a positive moisture balance in the previous winter season, as reflected by the positive relationship between radial growth and Palmer Drought Severity Index (PDSI) values (Palmer 1965, Piraino et al. 2013). Previous studies indicated a close relationship between stone pine radial growth and climatic factors, highlighting that tree ring formation in this species is sensitive to drought (Raventos et al. 2001, De Luis et al. 2009, Novak et al. 2011, Mazza et al. 2014). Thus, tree ring analysis in this species can be potentially useful in climate change studies in the Mediterranean basin, which is considered particularly vulnerable to climate alterations (Giorgi 2006).

Akkemik (2000) found that the temperature at the beginning of the growing period can have a significantly positive effect on tree ring growth, and concluded that $\mathrm{Pi}$ nus pinea $\mathrm{L}$. is a dendroclimatologically sensitive species. $P$. pinea has a drought-tolerant strategy, with a strongly reduced photosynthetic activity under water stress and elevated vapor pressure deficits (Awada et al. 2003), as commonly observed in summer and early autumn (Teobaldelli et al. 2004). These events might be detrimental for the radial growth of the species, inducing a decline of natural and artificial populations across most of its current range ( $\mathrm{Pi}$ raino et al. 2013). Thuiller et al. (2003a) highlighted the importance of extreme temperature in the ability of this species to survive and grow, thus affecting its geographical distribution. A negative relationship between temperature and growth has previously been observed in this species (Natalini et al. 2016), as well as in other Mediterranean pines (Martin-Benito et al. 2013). Natalini et al. (2013) also stressed the species vulnerability under increasing temperature due to climate change. Conse- quently, heat tolerance should be considered a key breeding trait for enhancing growth performances of stone pine. In Tunisia, Thabeet et al. (2007) reported a negative correlation between average temperature and growth, but with a superior threshold $\left(16^{\circ} \mathrm{C}\right)$. Novak et al. (2011) found that dry conditions from January to May, and high temperatures during late winter and spring were the main climatic factors promoting missing rings in Pinus pinea. Despite similarities, Pinus halepensis has proven to be more sensitive to drought than $P$. pinea early along the growing season, whereas the latter seems to be more sensitive to temperature variations during winter. Additionally, in both species, we found that the determining temperature has increased in recent periods. Late winter and spring maximum daily temperature values, associated with high evapotranspiration, were shown to negatively affect cell enlargement. However, minimum temperature was positively related to tracheid lumen size just before the period of active xylem formation. Moreover, Pinus pinea is sensitive to freezing temperatures (Abad Viñas et al. 2016).

\section{Water use by stone pine forests}

Pinus pinea is is a drought-avoiding isohydric species with a shallow root system which is able to reduce water flow during aridity and to recover when water becomes available again (Mayoral et al. 2015, Zalloni et al. 2016). The contrasting physiological strategies of Pinus pinea to cope with water deficit influence the regulation of growth processes, such as wood formation, leading to peculiar tree-ring anatomical features such as intra-annual density fluctuations (Zalloni et al. 2018). In a study focused on anatomical traits and composition of carbon and oxygen stable isotopes in the intra-annual density fluctuations (IADFs) occurring in tree rings, Zalloni et al. (2018) showed that the period of formation of IADF is autumn and the influence of climate on IADF occurrence is species-specific. Natalini et al. (2016) found that the growth-climate correlations varied by site and period. Intra-annual density fluctuation in stone pine has been related to the alternation of drought and rainy periods either in summer or autumn (Campelo et al. 2007, Nabais et al. 2014, Zalloni et al. 2016). The tree-ring growth response of Pinus pinea during winter, previously reported for

Tab. 1 - Model of plantation management for timber production. Source: Pereira et al. (2015) in Sbay \& Hajib (2016).

\begin{tabular}{cl}
\hline Age (years) & Operations and density ha ${ }^{-1}$ \\
\hline 0 & 850 trees ha ${ }^{-1}$ \\
10 & Thinning ( $41 \%$ cut : remains 500 trees ha $\left.^{-1}\right)$ \\
\hline 20 & Pruning mainly low branches \\
\hline 40 & Thinning (45\% cut : remains 225 trees ha-1 $\left.^{-1}\right)$ \\
\hline 80 to 150 & Final cut (rotation) leaving 10 trees ha-1 $^{-1}$ (seed trees) \\
\hline
\end{tabular}

Spain and Italy (De Luis et al. 2009, Mazza et al. 2014, Natalini et al. 2016), may reflect the physiological activity of this species during winter (Pardos et al. 2010). Balzano et al. (2019) found that in Mediterranean trees, cambium often produces several bands of alternating early- and latewood during a calendar year, resulting in the formation of IADFs. Tree-ring analysis in Pinus pinea showed a IADF region enriched in $\delta$ ${ }^{13} \mathrm{C}$ with an increasing trend in $\delta^{18} \mathrm{O}$, which suggests stomatal closure, and the decrease in stomatal conductance likely contributed to the increase in $\delta^{13} \mathrm{C}$ at the IADF level (De Micco et al. 2007). The high values of $\delta^{13} \mathrm{C}$ and $\delta^{18} \mathrm{O}$, along with the larger tracheids in the IADF region of Pinus pinea, suggest an enhancement of conductive efficiency leading to strict stomatal control with the aim of avoiding dehydration (Battipaglia et al. 2013). According to Balzano et al. (2019), stone pine trees on the Vesuvius Mountain (near Naples, Italy) showed uninterrupted wood production from January 2015 until the end of January 2016. The authors showed differences in cambium activity in late autumn among different years; in November 2015 and 2018, the cambium was still active and no longer active, respectively. Since radial growth generally starts at the treetop, the decreased availability of carbohydrates may cause reduced wood formation in the lowermost part of the tree. This was particularly noticeable in the Pinus halepensis, but not in P. pinea (Novak et al. 2011).

Pinus pinea earlywood anatomical features are the result of the typical double constraint of Mediterranean climate on tree growth: water shortage and, to a lesser extent, low winter temperature (Cherubini 1993). Based on records of annual growth rate, the response of stone pine to climate over the last 50 years also suggests the influence of precipitation and temperature regimes on growth (Cutini et al. 2014). These variables affect the soil water balance and are taken as the main factor driving tree growth decline, with a cumulative effect over consecutive years (Mazza et al. 2011). Mazza \& Manetti (2013) demonstrated the dependence of the species on long periods of water supply and its capacity of using the water content stored in previous rainy years. High air temperatures stimulate evapotranspiration and water loss (Battipaglia et al. 2009), thus leading to the drought-avoidant response and reduced stomatal conductance (Zalloni et al. 2018), as reflected by the presence of IADFs and high values of $\delta^{13} \mathrm{C}$ and $\delta^{18} \mathrm{O}$ in the wood of $P$. pinea. Intra-annual density fluctuations in Pinus pinea tree rings were also suggested to be formed during autumn months, as shown by the significant correlation found between IADF $\delta^{18} \mathrm{O}$ values and mean temperature (Campelo et al. 2007, Nabais et al. 2014, Zalloni et al. 2016). According to Castagneri et al. (2018), xylem anatomy of Pinus pinea is strongly related to the environmental conditions oc- 
Tab. 2 - Silvicultural systems for stone pine (source: Freire et al. 2016).

\begin{tabular}{|c|c|c|c|}
\hline Operation & Correia \& Oliveira (2002) & Louro et al. (2002) & INRB (2008) \\
\hline Initial density & 625 trees ha $^{-1}$ & 500 to 600 trees $\mathrm{ha}^{-1}$ & 208 to 400 trees $\mathrm{ha}^{-1}$ \\
\hline \multirow[t]{6}{*}{ Pruning } & \multirow{6}{*}{$\begin{array}{l}\text { Removal of branches without } \\
\text { female flowers (without } \\
\text { indication of periodicity) }\end{array}$} & 1/3 branches removal: & $1 / 3$ till $2 / 3$ branches removal: \\
\hline & & Between 8 and 12 years & Between 5 and 6 years \\
\hline & & Between 20 and 25 years & Between 10 and 12 years \\
\hline & & Removal of branches without female flowers: & Between 20 and 25 years \\
\hline & & Between 35 and 40 years & - \\
\hline & & Between 50 and 60 years & - \\
\hline \multirow[t]{4}{*}{ Thinning } & At 10 years till 500 trees $\mathrm{ha}^{-1}$ & 400 trees ha $^{-1}$ & Between 10 and 12 years \\
\hline & At 15 years till 300 trees $^{-1}$ & Between 20 and 25 years till 352 trees ha ${ }^{-1}$ & Between 20 and 25 years \\
\hline & At 31 years till 100 trees $\mathrm{ha}^{-1}$ & Between 25 and 30 years till 281 trees $^{-1}{ }^{-1}$ & - \\
\hline & - & Between 35 and 40 years till 225 trees ha $^{-1}$ & $\begin{array}{l}\text { No information on density after } \\
\text { thinning }\end{array}$ \\
\hline Final density & 100 trees ha $^{-1}$ & 225 trees ha $^{-1}$ & Between 100 and 120 trees ha $^{-1}$ \\
\hline Mean Distance & $10 \mathrm{~m}$ & $6.7 \mathrm{~m}$ & Between 10 and $9.2 \mathrm{~m}$ \\
\hline $\begin{array}{l}\text { Regeneration cut } \\
\text { (rotation) }\end{array}$ & At 80 years & Between 80 and 100 years & $\begin{array}{l}\text { No information about the } \\
\text { regeneration cut }\end{array}$ \\
\hline
\end{tabular}

curring in the previous season, particularly regarding tree-ring carbon composition, but it is not affected by summer drought. Indeed, earlywood is likely formed using both recently and formerly assimilated carbon, while latewood mostly relies on carbon accumulated many months prior to its formation. The direct relationship between xylem formation and intra-seasonal precipitation distribution is reflected in the intraring pattern of lumen size; earlywood tracheids are influenced by precipitation occurring before and during xylogenesis ( $\mathrm{Ca}$ marero et al. 2010, Vieira et al. 2015); latewood is mostly formed after the harsh summer period, when sandy soil is dry, photosynthesis is reduced (Calama et al. 2013, Flexas et al. 2014), and the limited amount of photosynthates available is used for metabolic functions (Dietze et al. 2014). Under these conditions, xylem formation may mostly depend on reserves. Furthermore, latewood $\delta^{13} \mathrm{C}$ was minimally associated with climatic conditions immediately before or during its formation, but was highly associated with the previous year $\delta^{13} \mathrm{C}$ and with temperature occurring several months before. Therefore, we suppose that the carbon used used for latewood formation came from mixing pools of different ages, in part older than one year (Timofeeva et al. 2017).

\section{Managing stone pine forests under climate change}

Rainfall reduction and temperature increase are challenging to stone pine management for cone production in the Mediterranean climate region. Therefore, it is necessary to adapt traditional silvicultural guidelines for stands facing climate change consequences, by reducing stand density over their lifetimes in order to ensure tree production in healthy mixed even-aged stands. In a study of the impact of climate and management variables in stone pine,
Pereira et al. (2015) proposed a plantation management model for timber production (Tab. 1). Loewe et al. $(2016,2017)$ reported that stone pine fertilization applied during two consecutive years is a useful tool to enhance DBH and height, and one year-old conelet production. These results confirm the benefits of establishing fertilized plantations for increasing growth and fruit production. Irrigation had an important effect on fruiting, but the effects on radial growth were not significant. Contrastingly, the irrigation effect was positive on both height and DBH growth when combined to fertilization (fertirrigation) in a 75 year-old plantation of limited growth and no management established in a clay-sand soil (Pestana 2000), with increases from 2 to $15 \mathrm{~mm}$ in diameter. Loewe et al. (2016) observed a positive effect on vertical growth, in agreement with the findings reported by Loewe \& Delard (2012). Freire et al. (2019) highlighted the importance of maintaining a small ratio between tree height and diameter, as it makes trees less susceptible to cavitation due to the reduced effort to transport water from the soil to leaves, as well as capable of maintaining their stomata open for longer periods, thereby in-

Tab. 3 - Proposals for final stand density (N), maximum crown diameter (Mcw), cone number (Mnc), weight (Mwc) per tree and average cone production per ha (Wc) (Freire et al. 2019).

\begin{tabular}{clrrrr}
\hline $\begin{array}{c}\mathbf{N} \\
\left(\text { trees ha }^{-1} \text { ) }\right.\end{array}$ & References & $\begin{array}{c}\text { Mcw } \\
(\mathbf{m})\end{array}$ & $\begin{array}{c}\text { Mnc } \\
(\mathbf{m})\end{array}$ & $\begin{array}{c}\text { Mwc } \\
(\mathbf{k g})\end{array}$ & $\begin{array}{c}\text { Wc } \\
\left(\mathbf{k g ~ h a}^{-1}\right)\end{array}$ \\
\hline 28 & Freire et al. (2016) & 18.9 & 2136 & 500.4 & 1124.3 \\
\hline 75 & Kuçuker \& Baskent (2017) & 11.6 & 1871 & 322.4 & 604.5 \\
\hline 78 & Pique-Nicolau et al. (2011) & 11.3 & 400 & 117.8 & 582.7 \\
\hline 100 & Pereira et al. (2015) & 10.0 & 349 & 90.4 & 422.7 \\
\hline 120 & INRB (2008) & 9.1 & 349 & 90.4 & 277.2 \\
\hline 150 & Manso et al. (2014) & 8.2 & 349 & 90.4 & 243.6 \\
\hline 225 & Louro et al. (2002) & 6.7 & 92 & 22.4 & 196.8 \\
\hline
\end{tabular}

creasing carbon assimilation for growth and cone production.

Forestry aimed to promote adaptation to climate change is based on the implementation of practices aimed to reduce vulnerability, and increase the adaptive capacity of forest species in relation to the most limiting factor in the Mediterranean area, i.e., water deficit (García-Güemes \& Calama 2015). To achieve this objective, each individual tree must keep the highest possible vigor in order to be less susceptible to pathogen attacks and more resistant to drought events (Kohler et al. 2010). Traditionally, Pinus pinea stands have been managed following a uniform shelterwood system, with a three stage regeneration cut, and two or three thinnings during rotation (Moreno-Fernández et al. 2013, Pereira et al. 2015). Freire et al. (2016) described silvicultural interventions appropriate for a stand of pine nuts (Tab. 2). Thinning regulates intra-specific and interspecific competition (Calama et al. 2019), thus increasing the availability of water and nutrients for each tree. Also, thinning favors soil parameters (Mazza et al. 2011) and tree characteristics (Molina \& Del Campo 2012), and mitigates the negative effects of drought (Gar- 


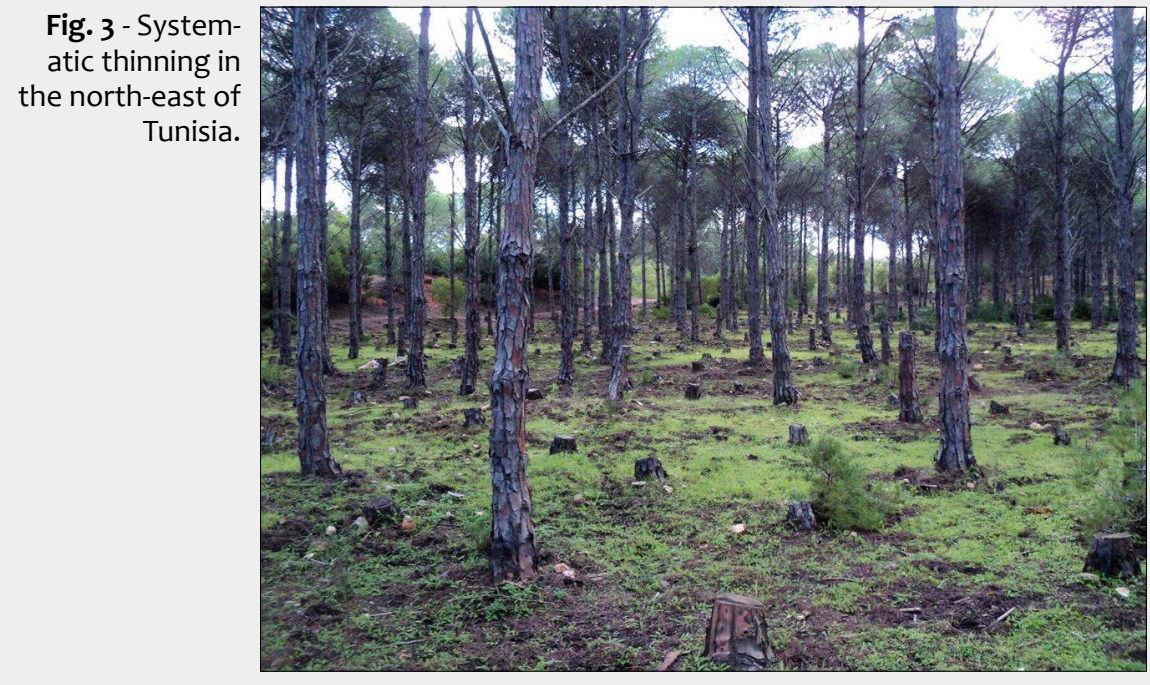

cía-Güemes \& Calama 2015, Guillemot et al. forestation practices because of its ecolog2015). According to McDowell et al. (2006), ical, economic, and aesthetic characteristhinning promotes physiological responses such as photosynthetic rate, carbon assimilation, and stomatal conductance, and reduces the effect of pests and diseases (Chowanski 2016), promoting the stability of stands by reducing the height/diameter ratio of trees (García-Güemes \& Calama 2015, Bošela et al. 2015), which is considered a mitigation measure against the detrimental effects of climatic changes (Mazza et al. 2011). Freire et al. (2019) proposed an optimal stand density, maximum crown diameter, cone number, weight per tree, and average cone production per ha (Tab. 3). In Tunisia, systematic thinning is applied in certain stands (Fig. 3) and sometimes the final cut, in silvicultural interventions (Fig. 4).

\section{Conclusions}

Stone pine (Pinus pinea L.) is naturally distributed in the Mediterranean forest ecosystem, and is frequently employed in af- tics. It is among the main species that provide an important contribution to the national economy, especially in terms of nonwood products. Climate change has negative effects on stone pine forests that have limited suitable habitats currently threatened by climatic change. Climatic models using different future scenarios predict that $P$. pinea will undergo habitat loss, thus shifting its geographical distribution. Treering analysis showed that winter and spring rainfall has positive effects on growth, whereas high spring temperature has the opposite effect. Stone pine growth is positively correlated with the Palmer Drought Severity Index (PDSI) and with annual rainfall, and negatively correlated with the maximum average annual temperature.

Forest management could play a fundamental role in reducing the potential impact of climate change on forest ecosystems. Good management of stone pine

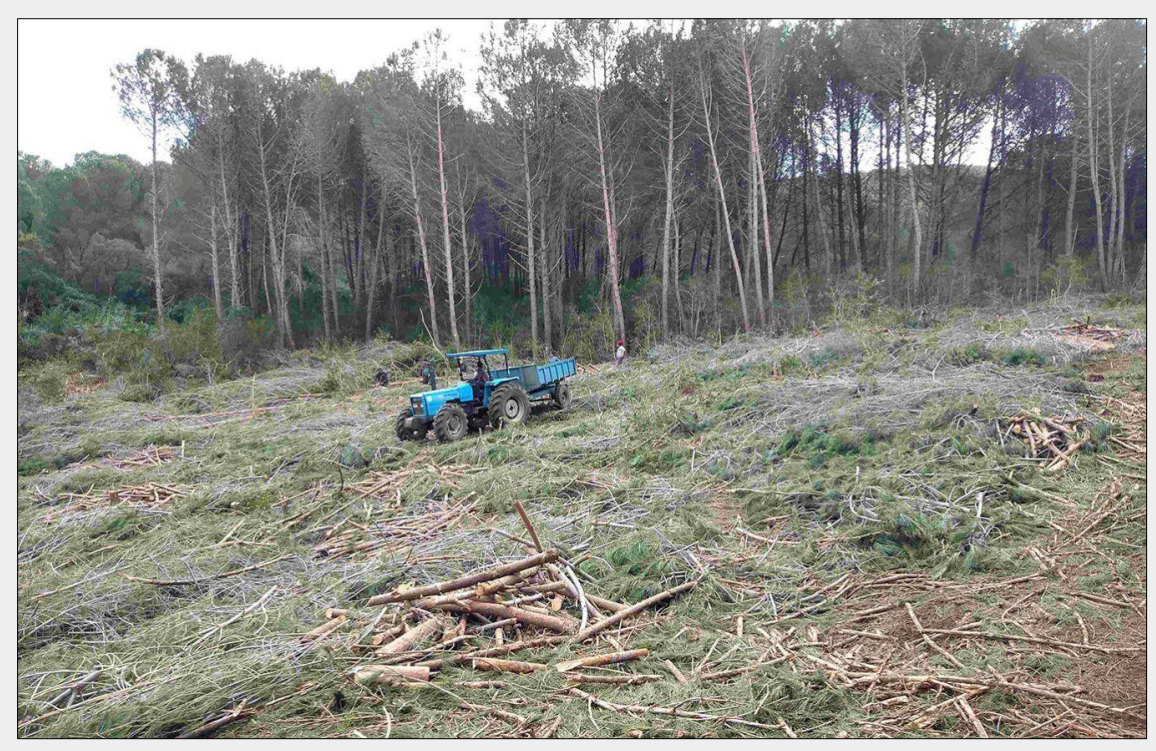

Fig. 4 - Final cut in stone pine stand in the north-west of Tunisia. forests and plantations should ensure effective adaptation to climate change. Silvicultural practices should be aimed at increasing species richness, favoring hardwoods currently growing under conifer canopy, as well as stimulating natural regeneration and gene flow. Special attention should be given to support migration processes, given the predicted shift of suitable habitats for the species.

\section{Conflict of interest}

The authors declare that they have no conflict of interest.

\section{Acknowledgments}

The authors would like to thank the Faculty of Science, Princess Nourah Bint Abdurrahman University, Riyadh (Saudi Arabia) and Silvo-Pastoral Institute of Tabarka, University of Jendouba, Jendouba (Tunisia).

\section{References}

Abad Viñas R, Caudullo G, Oliveira S, De Rigo D (2016). Pinus pinea in Europe: distribution, habitat, usage and threats. In: "European atlas of forest tree species" (San-Miguel-Ayanz J, de Rigo D, Caudullo G, Houston Durrant T, Mauri A eds). Publication Office of the European Union, Luxembourg, pp. 130-131. [online] URL: http:// www.researchgate.net/publication/299470758 Akkemik U (2000). Dendroclimatology of umbrella pine (Pinus pinea L.) in Istanbul, Turkey. Tree-Ring Bulletin 56: 17-20. [online] URL: http://repository.arizona.edu/handle/10150/262 533

Akyol A, Orucu OK (2019). Investigation and evaluation of stone pine (Pinus pinea L.) current and future potential distribution under climate change in Turkey. Cerne 25 (4): 415-432. - doi: 10.1590/01047760201925042643

Arduini I, Ercoli L (2012). Recovery of understory vegetation in clear-cut stone pine (Pinus pinea L.) plantations. Plant Biosystems 146 (S1): 244258. - doi: 10.1080/11263504.2012.679977 Awada T, Radoglou K, Fotelli MN, Constantinidou HIA (2003). Ecophysiology of seedlings of three Mediterranean pine species in contrasting light regimes. Tree Physiology 23: 33-41. doi: 10.1093/treephys/23.1.33

Balzano A, De Micco V, Merela M, Cufar K (2019). Tree-rings in mediterranean pines - Can we ascribe them to calendar years? Les/Wood 68 (1): 5-14. - doi: 10.26614/les-wood.2019.v68no1a01 Battipaglia G, Saurer M, Cherubini P, Siegwolf RTW, Cotrufo MF (2009). Tree rings indicate different drought resistance of a native (Abies alba Mill.) and a nonnative (Picea abies (L.) Karst.) species co-occurring at a dry site in Southern Italy. Forest Ecology and Management 257: 820-828. - doi: 10.1016/j.foreco.2008. 10.015

Battipaglia G, Saurer M, Cherubini P, Calfapietra C, Mc Carthy HR, Norby RJ, Cotrufo MF (2013). Elevated $\mathrm{CO}_{2}$ increases tree-level intrinsic water use efficiency: insights from carbon and oxygen isotope analyses in tree rings across three forest FACE sites. New Phytologist 197: 544-554. doi: 10.1111/nph.12044

Bede-Fazekas A, Horvath L, Kocsis M (2014). Im- 
pact of climate change on the potential distribution of Mediterranean pines. Idojaras 118: 4152. [online] URL: http://unipub.lib.uni-corvinus. hu/1511/

Bošela M, Konopka B, Seben V, Vladovic J, Tobin $B$ (2015). Modelling height to diameter ratio: an opportunity to increase Norway spruce stand stability in the Western Carpathians. Annals of Forest Science 72: 651-663. - doi: 10.1007/s135 95-015-0464-y

Bravo F, Lucà M, Mercurio R, Sidari M, Muscolo A (2011). Soil and forest productivity: a case study from Stone pine (Pinus pinea L.) stands in Calabria (southern Italy). iForest 4: 25-30. - doi: 10.3832/ifor0559-004

Calama R, Mutke S, Tomé J, Gordo J, Montero G, Tomé $M$ (2011). Modelling spatial and temporal variability in a zero-inflated variable: the case of stone pine (Pinus pinea L.) cone production. Ecological Modelling 222 (3): 606-618. - doi: 10.1016/j.ecolmodel.2010.09.020

Calama R, Puértolas J, Madrigal G, Pardos M (2013). Modeling the environmental response of leaf net photosynthesis in Pinus pinea L. natural regeneration. Ecological Modeling 251: 921. - doi: 10.1016/j.ecolmodel.2012.11.029

Calama R, Conde M, De-Dios-García J, Madrigal G, Vázquez-Piqué J, Gordo FJ, Pardos M (2019). Linking climate, annual growth and competition in a Mediterranean forest: Pinus pinea in the Spanish Northern Plateau. Agricultural and Forest Meteorology 264: 309-332. - doi: 10.1016/ j.agrformet.2018.10.017

Calama R, Gordo J, Mutke S, Conde M, Madrigal G, Garriga E, Arias MJ, Piqué M, Gandía R, Montero G, Pardos M (2020). Decline in commercial pine nut and kernel yield in Mediterranean stone pine (Pinus pinea L.) in Spain. iForest 13: 251-260. - doi: 10.3832/ifor3180-013

Camarero JJ, Olano JM, Parras A (2010). Plastic bimodal xylogenesis in conifers from continental Mediterranean climates. New Phytologist 185: 471-480. - doi: 10.1111/j.1469-8137.2009.0307 3.x

Campelo F, Nabais C, Freitas H, Gutiérrez E (2007). Climatic significance of tree-ring width and intra-annual density fluctuations in Pinus pinea from a dry Mediterranean area in Portugal. Annals of Forest Science 64: 229-238. - doi: 10.1051/forest:2006107

Castagneri D, Battipaglia G, Arx GV, Pacheco A, Marco Carrer M (2018). Tree-ring anatomy and carbon isotope ratio show both direct and legacy effects of climate on bimodal xylem formation in Pinus pinea. Tree Physiology 38: 10981109. - doi: 10.1093/treephys/tpy036

Caudullo G, Welk E, San-Miguel-Ayanz J (2017). Chorological maps for the main European woody species. Data in Brief 12: 662-666. . org. doi: 10.1016/j.dib.2017.05.007

Cherubini P (1993). Studio dendroecologico su Pinus pinea $L$. in due differenti stazioni sulla costa mediterranea in Toscana (Italia) [Dendroecological study on Pinus pinea L. in two different stations on the Mediterranean coast in Tuscany (Italy)]. Dendrochronologia 11: 87100. [in Italian]

Chowanski KM (2016). Developing management guidelines that balance cattle and timber production with ecological interests in the black hills of South Dakota. PhD Thesis, South Dakota
State University, Brookings, SD, USA, pp. 235. [online] URL: http://openprairie.sdstate.edu/cg i/viewcontent.cgi?article $=2099 \&$ context $=$ etd

Correia AV, Oliveira AC (2002). Principais espécies florestais com interesse para Portugal Zonas de influência Mediterrânea; Estudos e informação [Main forest species of interest to Portugal - Mediterranean influence zones; Studies and information]. Direcção Geral das Florestas, Lisboa, Portugal, pp. 77-84. [in Portuguese]

Cutini A, Chianucci F, Manetti MC (2013). Allometric relationships for volume and biomass for stone pine (Pinus pinea L.) in Italian coastal stands. iForest 6 (6): 331-335. - doi: 10.3832/ifor 0941-006

Cutini A, Manetti MC, Mazza G, Moretti V, Salvati L (2014). Climate variability, soil aridity, and growth rate of Pinus pinea L. in Castelporziano forest: an exploratory data analysis. Rendiconti Lincei 26: 413-420. - doi: 10.1007/s12210-0140335-8

De Luis M, Novak K, Cufar K, Raventós J (2009). Size mediated climate-growth relationships in Pinus halepensis and Pinus pinea. Trees-Structure and Function 23: 1065-1073. - doi: 10.1007/ soo468-009-0349-5

De Micco V, Saurer M, Aronne G, Tognetti R, Cherubini $P$ (2007). Variations of wood anatomy and $\delta^{13} \mathrm{C}$ within-tree rings of coastal Pinus pinaster showing intra-annual density fluctuations. IAWA Journal 28: 61-74. - doi: 10.1163/22 941932-90001619

Dietze MC, Sala A, Carbone MS, Czimczik Cl, Mantooth JA, Richardson AD, Vargas R (2014). Nonstructural carbon in woody plants. Annual Review of Plant Biology 65: 667-687. - doi: 10.1146/annurev-arplant-050213-040054

Doblas-Miranda E, Alonso R, Arnan X, Bermejo V, Brotons L, De Las Heras J, Estiarte M, Hodar JA, Llorens P, Lloret F, Lopez-Serrano FR, MartnezVilalta J, Moya D, Penuelas J, Pino J, Rodrigo A, Roura-Pascual N, Valladares F, Vila M, Zamora $R$, Retana J (2016). A review of the combination among global change factors in forests, shrublands and pastures of the Mediterranean Region: beyond drought effects. Global and Planetary Change 148 (6): 42-54. - doi: 10.1016/j.glopla cha.2016.11.012

El-Khorchani A, Gadbin-Henry C, Bouzid S, Khaldi A (2007). Impact de la sécheresse sur la croissance de trois espèces forestières en Tunisie (Pinus halepensis Mill., Pinus pinea L. et Pinus pinaster Sol.) [Impact of drought on the growth of three forest species in Tunisia (Pinus halepensis Mill., Pinus pinea L. and Pinus pinaster Sol.)]. Sécheresse 18 (2): 113-121. [in French] [online] URL: http://www.researchgate.net/pu blication/299496017

Fady B, Fineschi S, Vendramin GG (2004). EUFORGEN technical guidelines for genetic conservation and use for Italian stone pine (Pinus pinea). International Plant Genetic Resources Institute, FAO, Rome, Italy, pp. 6. [online] URL: http://books.google.com/books?id=Z5AhkIWzie oc

Flexas J, Diaz-Espejo A, Gago J, Gallé A, Galmés J, Gulías J, Medrano H (2014). Photosynthetic limitations in Mediterranean plants: a review. Environmental and Experimental Botany 103: 12-23. - doi: 10.1016/j.envexpbot.2013.09.002
Franklin J (2013). Species distribution models in conservation biogeography: developments and challenges. Diversity and Distributions 19 (10): 1217-1223. - doi: 10.1111/ddi.12125

Freire JPA, Tomé M, Silva CS, Telles MR (2016). Silvicultural guidelines for managing $P$. pinea stands in a southeastern Portuguese region for cone production. In: "Revised Silvicultural Guidelines for selected MPT and NWFPs" (Sheppard J, Mangold L, Spiecker H eds). StarTree Deliverable 2.3, FP7 Project No 311919 KBBE 2012 (1): 2-06. European Commission, Brussels, Belgium, pp. 113.

Freire JA, Rodrigues GC, Tomé M (2019). Climate change impacts on Pinus pinea L. silvicultural system for cone production and ways to contour those impacts: a review complemented with data from permanent plots. Forests 10: 152-169. - doi: 10.3390/f10020169

García-Güemes C, Calama R (2015). La práctica de la selvicultura para la adaptación al cambio climático [The practice of forestry for adaptation to climate change]. In: "Los Bosques y La Biodiversidad Frente al Cambio Climático: Impactos, Vulnerabilidad y Adaptación en España" (Zavala MA ed). Chapter 46, Ministerio para la Transición Ecológica, Madrid, Spain, pp. 12. [in Spanish]

Gea-Izquierdo G, Cherubini P, Cañellas I (2011). Tree-rings reflect the impact of climate change along a temperature gradient in Spain over the last 100 years. Forest Ecology and Management 262: 1807-1816. - doi: 10.1016/j.foreco.2011.07.0 25

Giorgi F (2006). Climate change hot-spots. Geophysical Research Letters 33 (8): 89. - doi: 10.01029/02006GL025734

Guillemot E, Klein EK, Davi H, Coubert F (2015). The effects of thinning intensity and tree size on the growth response to annual climate in Cedrus atlantica: a linear mixed modeling approach. Annals of Forest Science 72: 651-663. doi: 10.1007/s13595-015-0464-y

Guisan A, Thuiller W (2005). Predicting species distribution: offering more than simple habitat models. Ecology Letters 8: 993-1009. - doi: 10.1111/j.1461-0248.2005.00792.x

INRB (2008). Condução de povoamentos de pinheiro manso e características nutricionais do pinhão [Driving of pine trees and nutritional characteristics of pine nuts]. Instituto Nacional dos Recursos Biológicos, IP, Oeiras, Portugal, pp. 50. [in Portuguese]

Jaouadi W, Mechergui K, Riahi MA, Khouja ML (2018). Effect of thinning on Pinus pinea L. development and physico-chemical soil characteristics in northwestern Tunisia: modeling of radial growth under thinning intensity. Dendrobiology 80: 70-80. - doi: 10.12657/denbio.080.007 Keenan RJ, Reams GA, Achard F, De Freitas JV, Grainger A, Lindquistf E (2015). Dynamics of global forest area: results from the FAO Global Forest Resources Assessment 2015. Forest Ecology and Management 352: 9-20. - doi: 10.1016/j. foreco.2015.06.014

Kohler M, Nägele G, Sohn S, Bauhus J (2010). The impact of different thinning regimes on the drought tolerance of Norway Spruce (Picea abies). European Journal of Forest Research 129: 1109-1118. - doi: 10.1007/s10342-010-0397-9 Kovats RS, Valentini R, Bouwer LM, Georgo- 
poulou E, Jacob D, Martin E, Rounsevell $M$, Soussana JF (2014). Europe. In: "Climate change: Impacts, adaptation, and vulnerability Part B: regional aspects" (Barros VR, Field CB, Dokken DJ, Mastrandrea MD, Mach KJ, Bilir TE, Chatterjee M, Ebi KL, Estrada YO, Genova RC, Girma B, Kissel ES, Levy AN, MacCracken S, Mastrandrea PR, White LL eds). Contribution of working group II to the fifth assessment report of the intergovernmental panel on climate change. Cambridge University Press, Cambridge, pp. 1267-1326.

Kuçuker DM, Baskent EZ (2017). State of stone pine forests in Turkey and their economic im portance for rural development. Options Méditerrannénnes 122: 110-117.

Loewe MV, Delard RC (2012). Un nuevo cultivo para Chile, el pino pinonero (Pinus pinea $L$ ) $[A$ new crop for Chile, the stone pine (Pinus pinea L.)]. Instituto Forestal, Chile, pp. 364. [in Spanish]

Loewe MV, Balzarini M, Delard Rodriguez C, Alvarez Contreras A, Navarro-Cerrillo RM (2016) Growth of Stone pine (Pinus pinea L.) European provenances in central Chile. iForest 10 (1): 64 69. - doi: 10.3832/ifor1984-009

Loewe MV, Alvarez A, Balzarini M, Delard C, Navarro-Cerri R (2017). Mineral fertilization and irrigation effects on fruiting and growth in stone pine (Pinus pinea L.) crop. Fruits 72 (5): 281-287. - doi: $10.17660 /$ th2017/72.5.3

Loewe MV, Delard C (2019). Stone pine (Pinus pinea L.): an interesting species for agroforestry in Chile. Agroforestry Systems 93 (2): 703 713. - doi: 10.1007/s10457-017-0166-6

Lopez-Tirado J, Hidalgo PJ (2016). Ecological niche modelling of three Mediterranean pine species in the south of Spain: a tool for affor estation/reforestation programs in the twenty first century. New Forests 47: 411-429. - doi 10.1007/s11056-015-9523-3

Louro G, Marques H, Salinas HF (2002). Elementos de apoio à elaboração de projectos flores tais [Elements of support for the development of forestry projects] ( $2^{\text {nd }}$ edn). Estudos e informação 321, Direcção Geral das Florestas, Lis boa, Portugal, pp. 126. [in Portuguese]

Manso R, Pukkala T, Pardos M, Miina J, Calama R (2014). Modelling Pinus pinea forest management to attain natural regeneration under present and future climatic scenarios. Canadian Journal of Forest Research 44: 250-262. - doi: 10.1139/cjfr-2013-0179

Martin-Benito D, Beeckman H, Canellas I (2013). Inflence of drought on tree rings and tracheid features of Pinus nigra and Pinus sylvestris in a mesic Mediterranean forest. European Journa of Forest Research 132 (1): 33-45. - doi: 10.1007 s10342-012-0652-3

Martinez FG, Montero R, Ruiz-Peinado I, Canellas JA, Candela A (2004). Geobotanica e historia de los pinares [Geobotany and history of the pine forests]. In: "El Pino pinonero (Pinus pinea L.) en Andalucia: Ecologia, distribucion y selvicul tura" (Montero G, Candela JA, Fernandez A eds). Consejeria de Medio Ambiente, Junta de Andalucia, Sevilla, Spain, pp. 49-111. [in Spanish] Mayoral C, Calama R, Sánchez-González M, Pardos M (2015). Modelling the influence of light, water and temperature on photosynthesis in young trees of mixed Mediterranean forests.
New Forest 46: 485-506. - doi: 10.1007/s11056-01 5-9471-y

Mazza G, Amorini E, Cutini A, Manetti MC (2011). The influence of thinning on rainfall interception by Pinus pinea L. in Mediterranean coastal stands (Castel Fusano - Rome). Annals of Forest Science 68: 1323-1332. - doi: 10.1007/s13595011-0142-7

Mazza G, Cutini A, Manetti MC (2014). Site-specific growth responses to climate drivers of $\mathrm{Pi}$ nus pinea $\mathrm{L}$. tree rings in Italian coastal stands. Annals of Forest Science 71 (8): 927-936. - doi: 10.1007/s13595-014-0391-3

Mazza G, Manetti M (2013). Growth rate and climate responses of Pinus pinea $L$. in Italian coastal stands over the last century. Climatic Change 121 (4): 713-725. - doi: 10.1007/s10584013-0933-y

McDowell NG, Adams HD, Bailey JD, Hess M, Kob TE (2006). Homeostatic maintenance of ponderosa pine gas exchange in response to stand density changes. Ecological Applications 16: 1164-1182. - doi: 10.1890/1051-0761(2006)016 [1164:HMOPPG]2.0.CO;2

Molina AJ, Del Campo AD (2012). The effects of experimental thinning on throughfall and stem flow: a contribution towards hydrology-oriented silviculture in Aleppo pine plantations. Forest Ecology and Management 269: 206-213. doi: 10.1016/j.foreco.2011.12.037

Moreno-Fernández D, Cañellas I, Calama R, Gordo J, Sánchez-González M (2013). Thinning increases cone production of Stone pine (Pinus pinea L.) stands in the Northern Plateau (Spain). Annals of Forest Science 70 (8): 761768. - doi: 10.1007/s13595-013-0319-3

Mutke S, Calama R, Gordo J, Gil L (2007). El uso del pino piñonero como especie de frutal en sistemas agroforestales de secano [The use of stone pine as a fruit tree species in rainfed agroforestry systems]. Cuadernos de la Sociedad Española de Ciencias Forestales 22: 137-142. [in Spanish] - doi: 10.31167/csef.voi22.9593

Mutke S, Calama R, Gonzalez-Martinez SC, Montero G, Javier Gordo F, Bono D, Gil L (2012). Mediterranean stone pine: botany and horticulture. Horticultural Reviews 39 (1): 153-201. - doi: 10.1002/9781118100592.ch4

Nabais C, Campelo F, Vieira J, Cherubini P (2014). Climatic signals of tree-ring width and intra-annual density fluctuations in Pinus pinaster and Pinus pinea along a latitudinal gradient in Portugal. Forestry 87: 598-605. - doi: 10.1093/forestry /cpu021

Natalini F, Alejano MR, Vásquez-Piqué J, Canellas I, Gea-Izquierdo G (2013). Dendroecología de Pinus pinea en el suroeste de Espana y su aplicación para elestudio de la vulnerabilidad de especies forestales ante el cambio global [Dendroecology of Pinus pinea L. in southwestern Spain and its application to study the vulnerability of forest species to global change]. In: "Actas $6^{\circ}$ Congreso Forestal Español", Chapter 068. Sociedad Española de Ciencias Forestales, Madrid, Spain, pp. 2-12. [in Spanish]

Natalini F, Correia AC, Vazquez-Piqué J, Alejano R (2015). Tree rings reflect growth adjustments and enhanced synchrony among sites in Iberian stone pine (Pinus pinea L.) under climate change. Annals of Forest Science 72 (8): 10231033. - doi: 10.1007/s13595-015-0521-6
Natalini F, Alejano R, Vazquez-Piqué J, Pardos M, Calama R, Buetgen U (2016). Spatiotemporal variability of stone pine (Pinus pinea L.) growth response to climate across the Iberian Peninsula. Dendrochronologia 40: 72-84. - doi: 10.101 6/j.dendro.2016.07.001

Novak K, De Luis M, Cufar K, Raventós J (2011). Frequency and variability of missing tree rings along the stems of Pinus halepensis and Pinus pinea from a semiarid site in SE Spain. Journal of Arid Environment 75: 494-498. - doi: 10.1016/ j.jaridenv.2010.12.005

Ovando P, Campos P, Calama R, Montero G (2010). Landowner net benefit from Stone pine (Pinus pinea L.) afforestation of dry-land cereal fields in Valladolid, Spain. Journal of Forest Economics 16 (2): 83-100. - doi: 10.1016/j.jfe.2009. 07.001

Palmer JG (1965). Meteorological drought. US Research Paper no. 45, US Weather Bureau, Washington, DC, USA, pp. 58. [online] URL: http://books.google.com/books?id=kyYZgnEk-L $8 \mathrm{C}$

Pardos M, Puértolas J, Magrigal G, Garriga E, De Blas S, Calama R (2010). Seasonal changes in the physiological activity of regeneration under a natural light gradient in a Pinus pinea regular stand. Forest Systems 19 (3): 367-380. - doi: 10.5424/fs/2010193-9102

Pardos M, Calama R, Maroschek M, Rammer W, Lexer MJ (2015). A model-based analysis of climate change vulnerability of Pinus pinea stands under multi-objective management in the Northern Plateau of Spain. Annals of Forest Science 72 (8): 1009-1021. - doi: 10.1007/s13595-0150520-7

Pecchi M, Marchi M, Moriondo M, Forzierin G, Ammoniaci $M$, Bernetti $M$, Bindi I, Chirici M (2020). Potential impact of climate change on the spatial distribution of key forest tree species in Italy under RCP4.5 for 2050s. Research Square. [preprint] - doi: 10.21203/rs.3.rs20281/v1

Pereira S, Prieto A, Calama R, Diaz-Balteiro L (2015). Optimal management in Pinus pinea L. stands combining silvicultural schedules for timber and cone production. Silva Fennica 49 (3): art1226. - doi: 10.14214/sf.1226

Pestana EV (2000). El pino pinonero árbol frutal [Stone pine fruit tree]. In: Proceedings of the " $1^{\text {st }}$ Symposium on Stone pine". Valladolid (Spain), vol. 2, pp. 279-284. [in Spanish] Pique-Nicolau M, Del-Rio M, Calama R, Montero $G$ (2011). Modelling silviculture alternatives for managing Pinus pinea L. forest in North-East Spain. Forest Systems 20: 3-30. - doi: 10.5424/fs/ 2011201-8464

Piraino S, Camiz S, Di Filippo A, Piovesan G, Spada $F$ (2013). A dendrochronological analysis of Pinus pinea $\mathrm{L}$. on the Italian mid-Tyrrhenian coast. Geochronometria 40 (1): 77-89. - doi: 10.2478/s13386-012-0019-z

Quézel P, Médail F (2003). Ecologie et biogéographie des forêts du bassin Méditerranéen [Ecology and biogeography of forests in the Mediterranean basin]. Elsevier Masson, Paris, France, pp. 573. [in French]

Raventos J, De Luis M, Gras MJ, Cufar K, Gonzalez-Hidalgo JC, Bonet A, Sanchez JR (2001). Growth of Pinus pinea and Pinus halepensis as affected by dryness and marine spray in a semi- 
arid sand dune ecosystem. Dendrochronologia 19: 211-220.

Sánchez-Salguero R, Linares JC, Camarero JJ, Madrigal-González J, Hevia A, Sánchez-Miranda A, Ballesteros-Cánovas J, Alfaro-Sánchez R, García-Cervigón Al, Bigler C, Rigling A (2015). Disentangling the effects of competition and climate on individual tree growth: a retrospective and dynamic approach in Scots pine. Forest Ecology and Management 358: 12-25. - doi: 10.1016/j.for eco.2015.08.034

Sbay $\mathrm{H}$, Hajib S (2016). Le pin pignon: une espèce de choix dans le contexte des changements climatiques [Stone pine: a species of choice in the context of climate change]. Centre de Recherches Forestières, Maroc, pp. 76. [in French]

Serra Varela MJ (2018). Integrating infra-specific variation of Mediterranean conifers in species distribution models. Applications for vulnerability assessment and conservation. PhD thesis, Universidad de Valladolid, Spain, pp. 284.

Teobaldelli M, Mencuccini M, Piussi P (2004). Water table salinity, rainfall and water use by umbrella pine trees (Pinus pinea L.). Plant Ecology 171: 23-33. - doi: 10.1023/B:VEGE.00000293 84.40192.cc
Thabeet A, Denelle N, El Khorchani A, Thomas A, Gadbin-Henry C (2007). Etude dendroclimatologique de quatre populations de pin pignon en Tunisie [Dendroclimatological study of four pine populations in Tunisia]. Forêt Méditerrannenne 28 (3): 219-228. [in French]

Thuiller W, Araujo MB, Lavorel S (2003a). Generalized models vs. classification tree analysis: predicting spatial distributions of plant species at different scales. Journal of Vegetation Science 14: 669-680. - doi: 10.1111/j.1654-1103.2003.t b02199.x

Thuiller W, Vaireda J, Pino J, Sabate S, Lavorel S, Gracia C (2003b). Large scale environmental correlates of the forest tree distributions in Catalogna (NE Spain). Global Ecology and Biogeography 12: 313-325. - doi: 10.1046/j.1466-822 X.2003.00033.X

Timofeeva G, Treydte K, Bugmann H, Rigling A, Schaub M, Siegwolf R, Saurer M (2017). Longterm effects of drought on tree-ring growth and carbon isotope variability in Scots pine in a dry environment. Tree Physiology 8: 1028-1041. doi: 10.1093/treephys/tpx041

Vieira J, Campelo F, Rossi S, Carvalho A, Freitas $\mathrm{H}$, Nabais C (2015). Adjustment capacity of mar- itime pine cambial activity in drought-prone environments. PLoS One 10: 1-15. - doi: 10.1371/jour nal.pone. 0126223

Zalloni E, Battipaglia G, Cherubini P, Saurer M, De Micco V (2018). Contrasting physiological responses to Mediterranean climate variability are revealed by intra-annual density fluctuations in tree rings of Quercus ilex L. and Pinus pinea L. Tree Physiology 38: 1213-1224. - doi: 10.1093/treephys/tpyo61

Zalloni E, de Luis M, Campelo F, Novak K, De Micco V, Di Filippo A, Vieira J, Nabais C, Rozas V, Battipaglia $G$ (2016). Climatic signals from intraannual density fluctuation frequency in Mediterranean pines at a regional scale. Frontiers in Plant Science 7 (136305): 859. - doi: 10.3389/ fpls.2016.00579

Zank C, Becker FG, Abadie M, Baldo D, Maneyro $R$, Borges-Martins M (2014). Climate change and the distribution of neotropical red-bellied toads (Melanophryniscus, Anura, Amphibia): how to prioritize species and populations? PLoS One 9 (4): e94625. - doi: 10.1371/journal. pone.0094625 